\title{
Molecular identification of Giardia duodenalis in Ecuador by polymerase chain reaction-restriction fragment length polymorphism
}

\author{
Richard Atherton ${ }^{1 /+}$, Darlene Bhavnani ${ }^{2}$, Manuel Calvopiña ${ }^{1}$, \\ Yosselin Vicuña', William Cevallos ${ }^{1}$, Joseph Eisenberg ${ }^{2}$ \\ ${ }^{1}$ Centro de Biomedicina, Universidad Central del Ecuador, Quito, Pichincha, Ecuador \\ ${ }^{2}$ Department of Epidemiology, School of Public Health, University of Michigan, Ann Arbor, MI, USA
}

\begin{abstract}
The aim of this study was to determine the genetic diversity of Giardia duodenalis present in a human population living in a northern Ecuadorian rain forest. All Giardia positive samples (based on an ELISA assay) were analysed using a semi-nested polymerase chain reaction-restriction fragment length polymorphism assay that targets the glutamate dehydrogenase (gdh) gene; those amplified were subsequently genotyped using NlaIV and RsaI enzymes. The gdh gene was successfully amplified in 74 of 154 ELISA positive samples; 69 of the 74 samples were subsequently genotyped. Of these 69 samples, 42 (61\%) were classified as assemblage B (26 as BIII and 16 as BIV), 22 (32\%) as assemblage A (3 as AI and 19 as AII) and five (7\%) as mixed AII and BIII types. In this study site we observe similar diversity in genotypes to other regions in Latin America, though in contrast to some previous studies, we found similar levels of diarrheal symptoms in those individuals infected with assemblage B compared with those infected with assemblage $A$.
\end{abstract}

Key words: Ecuador - Giardia duodenalis - genotypes - PCR-RFLP - glutamate dehydrogenase

A variety of molecular tools including polymerase chain reaction-restriction fragment length polymorphism (PCR-RFLP), isoenzymes analysis and sequence analysis of several genes have provided genotypic information about Giardia duodenalis (Read et al. 2004, Cordón et al. 2008, Tungtrongchitr et al. 2010, Feng \& Xiao 2011, Pestehchian et al. 2012). Based on these analyses, isolates of $G$. duodenalis have been classified into seven genetic assemblages, A-G (Thompson et al. 2000, Read et al. 2004). Assemblages A and B, infect humans as well as a number of other hosts, whereas the other genetic assemblages $\mathrm{C}-\mathrm{G}$ are restricted to domestic animals, livestock and wild animals (Bertrand et al. 2005). Assemblage A, in humans has been classified into two groups, I and II and assemblage B has been classified into groups, III and IV (Thompson et al. 2000). PCRRFLP has been used previously to target the glutamate dehydrogenase ( $g d h)$ locus. This gene has been shown to be a reliable, easy and cost-effective method to identify G. duodenalis isolates directly from faeces (Thompson et al. 2000, Cordón et al. 2008, Fallah et al. 2008, Tungtrongchitr et al. 2010, Pestehchian et al. 2012). Studies on the relationship between parasite genotype and symptoms have been mixed, though a genotypic analysis using PCR-RFLP amplification of the $g d h$ gene did find a strong genetic link with clinical symptomatology in 18 Dutch patients (Homan \& Mank 2001).

doi: 10.1590/0074-0276108042013019

Financial support: NIH (RO1-AI050038)

+ Corresponding author: richard.atherton@hotmail.co.uk

Received 19 July 2012

Accepted 18 April 2013
G. duodenalis is a common parasite in Ecuadorian children living in rural communities, with prevalence measures of approximately $20 \%$ (Rinne et al. 2005, Jacobson et al. 2007). This is in agreement with five years of case control data collected from the communities included in this study (Bhavnani et al. 2012).

We report here for the first time the genotypes of $G$. duodenalis present in humans in rural communities in the northern coastal rainforests of Ecuador.

The study was conducted in North-western Ecuador within the province of Esmeraldas and the canton Eloy Alfaro. The study region comprises approximately 150 villages located along the three rivers, Cayapas, Santiago and Onzole. Between November 2004-July 2005, 595 stool samples were collected from 152 cases (diarrhoea) and 443 controls and frozen in liquid nitrogen before being transported to the lab in Quito. In Quito, the presence of Giardia antigen was tested using an ELISA kit (RIDASCREEN Giardia, R-Biopharm, USA).

DNA extraction was performed on the 154 faecal samples that were positive for infection by ELISA and samples were stored at $-20^{\circ} \mathrm{C}$ until required for PCR and RFLP analysis. DNA extraction, PCR [using primers GDHeF, GDHiF and GDHiR to identify a fragment of approximately 432 base pairs (bp) of the $g d h$ ] and RFLP was exactly as described by Read et al. (2004) and Cordón et al. (2008) with the following changes: the concentration of the forward primers in the PCR reaction were changed to $25 \mathrm{pmol}$ to improve sensitivity; RFLP digestion was increased to four units for $8 \mathrm{~h}$ at $37^{\circ} \mathrm{C}$ to improve cleavage by the restriction enzymes NlaIV and RsaI. PCR amplification of samples included a known Giardia positive (courtesy of Baca Ortiz Hospital, Quito) and a negative control (PCR water instead of DNA). Giardia RFLP assemblages were identified using a diagnostic genotyping profile as shown previously by 
TABLE I

A summary of ELISA test results in case and control stool samples

\begin{tabular}{lcccc}
\hline Infection status & $\begin{array}{c}\text { Giardia-negative } \\
(\mathrm{n})\end{array}$ & $\begin{array}{c}\text { Giardia-positive } \\
(\mathrm{n})\end{array}$ & $\begin{array}{c}\text { Not tested } \\
(\mathrm{n})\end{array}$ & $\begin{array}{c}\text { Total } \\
(\mathrm{n})\end{array}$ \\
\hline Diarrhoea & 85 & 66 & 1 & 152 \\
No diarrhoea & 353 & 88 & 2 & 443 \\
\hline Total & 438 & 154 & 3 & 595 \\
\hline
\end{tabular}

Read et al. (2004) and Babaei et al. (2008). One positive control identified as assemblage AII and another as assemblage BIII were used as references for the RFLP.

The estimated weighted prevalence of Giardia infection in our study population was $24 \%$. All but three stool samples were analysed for Giardia using ELISA. Of the 592 samples analysed, 154 (26\%) were positive for Giardia (Table I). Subsequently, all ELISA-positive samples were analysed by semi-nested PCR and 74 (48\%) exhibited a band at $432 \mathrm{bp}$ specific for the $g d h$ gene (Fig. 1). Of these 74 samples, 69 were genotyped using RFLP (Table II), with the NlaIV restriction enzyme used to distinguish between assemblage A and assemblage B genotypes (Fig. 2A). Those identified as assemblage B were further processed using the RsaI restriction enzyme (Fig. 2B). Five (7\%) samples that were PCR-positive could not be genotyped because the bands could not be clearly identified. These samples were excluded from our analysis.

In our study, all four genotypes were identified and the presence/absence of diarrhoea examined (Table III). Assemblage B was seen to be predominant (42 of 69 or $61 \%$ ) with group BIII the most common of the four genotypes $(26$ or $38 \%)$. This is in agreement with previous studies (Amar et al. 2002, Bertrand et al. 2005, Lebbad et al. 2008, Minvielle et al. 2008, Aldana et al. 2011, Molina et al. 2011). Assemblage A was found in 22 of the 69 isolates $(32 \%)$ with group II (19 of 69 or $28 \%$ ) the most common. Assemblage BIV was found in $16(23 \%)$ and only three individuals were infected with Group AI (4\%); this low frequency is consistent with the literature (Amar et al. 2002, Bertrand et al. 2005, Babaei et al. 2008). Interestingly, five individuals (7\%) in this study were co-infected with both genotypes AII and BIII, which also has been previously documented (Amar et al. 2002, Babaei et al. 2008, Molina et al. 2011). Overall, the odds ratio (OR) of diarrhoea in individuals infected with Giardia, compared to those uninfected, was 3.11 $(95 \% \mathrm{CI}=2.11,5.10)$. The OR of diarrhoea associated with assemblages B and A, each compared to no infection with Giardia, were 2.94 [95\% confidence interval $(\mathrm{CI})=1.45,5.81]$ and $3.46(95 \% \mathrm{CI}=1.83,9.24)$, respectively. The associations between diarrhoea and specific genotypes within assemblage $\mathrm{A}$ and $\mathrm{B}$ were similar to those reported above (Table IV).

Some prior studies have suggested that assemblage A infections are more likely to cause diarrhoea than assemblage B (Read et al. 2002, Haque et al. 2005, Cordón et al.

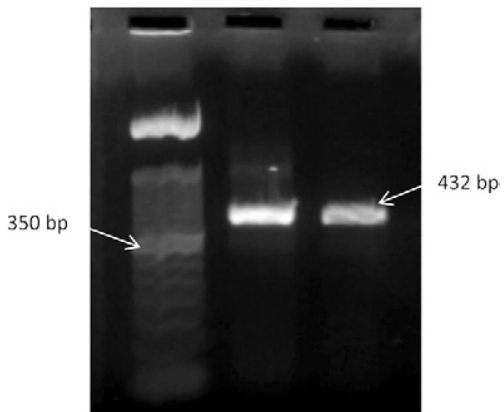

Fig. 1: amplification of the 432 base pairs (bp) band specific for the glutamate dehydrogenase gene of Giardia duodenalis. Lane 1: molecular weight marker 1,000 bp; 2: Giardia positive control 432 bp; 3: Giardia positive $432 \mathrm{bp}$.

\section{TABLE II}

Summary of expected band sizes from Giardia duodenalis glutamate dehydrogenase polymerase chain reaction-restriction fragment length polymorphism

\begin{tabular}{lcc}
\hline $\begin{array}{l}\text { Assemblage } \\
\text { and group }\end{array}$ & $\begin{array}{c}\text { Restriction } \\
\text { enzyme }\end{array}$ & $\begin{array}{c}\text { Diagnostic band size } \\
\text { (base pairs) }\end{array}$ \\
\hline AI & N1aIV & $90,120,150$ \\
AII & N1aIV & $70,80,90,120$ \\
BIII & RsaI & 130,300 \\
BIV & RsaI & 430 \\
AII, BIII & NlaIV and RsaI & $90,120,290,130,300$ \\
\hline
\end{tabular}

2008, Sahagún et al. 2008); we, however, found no evidence of differential pathogenicity between assemblage A and $\mathrm{B}$, which was in agreement with findings by García et al. (2002) and Ceu Souza and Poiares da Silva (2004).

Of the 154 ELISA-positive samples analysed for the presence of the $g d h$ gene, only $74(48 \%)$ were positive, likely due to low numbers of cysts in the faeces of some of our samples. This lack of PCR sensitivity for the $g d h$ gene has been noted by other groups, such as Amar et al. (2002), Cordón et al. (2008) and Tungtrongchitr et al. (2010), who also suggested that absence of this band was 
TABLE III

Frequency of symptomatic individuals (diarrhoea) across Giardia duodenalis genotypes

\begin{tabular}{lccccccc}
\hline Infection status & $\begin{array}{c}\text { AI } \\
\text { (n) }\end{array}$ & $\begin{array}{c}\text { AII } \\
\text { (n) }\end{array}$ & $\begin{array}{c}\text { BIII } \\
\text { (n) }\end{array}$ & $\begin{array}{c}\text { BIV } \\
\text { (n) }\end{array}$ & $\begin{array}{c}\text { Not determined } \\
\text { (n) }\end{array}$ & $\begin{array}{c}\text { Mix } \\
\text { (n) }\end{array}$ & $\begin{array}{c}\text { Giardia-negative } \\
(\mathrm{n})\end{array}$ \\
\hline Diarrhoea & 1 & 9 & 10 & 7 & 3 & 2 & 85 \\
No diarrhoea & 2 & 10 & 15 & 9 & 2 & 3 & 353 \\
Unknown & 0 & 0 & 1 & 0 & 0 & 5 & 5 \\
\hline Total & 3 & 19 & 26 & 16 & 5 & 538 \\
\hline
\end{tabular}
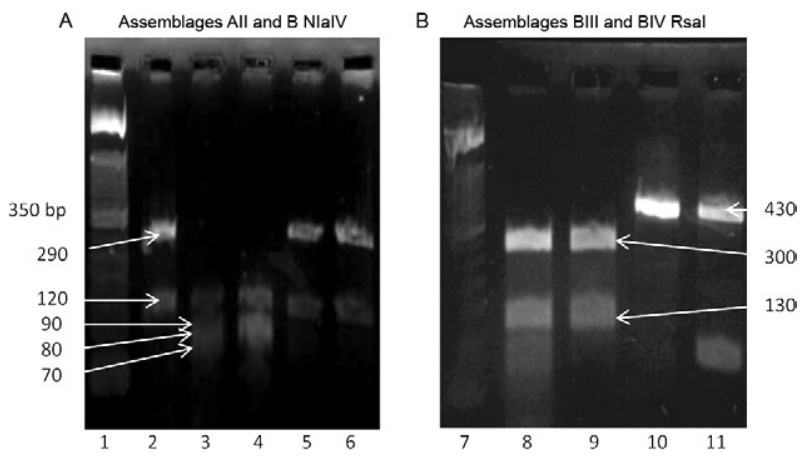

Fig. 2: ethidium bromide stained $2 \%$ high-resolution agarose gel showing DNA amplified at the glutamate dehydrogenase for genetic assemblages AII and B digested with Nla IV (A) and genetic assemblages BIII and BIV digested with RsaI (B). Lane 1: molecular weight marker 1,000 base pairs (bp); 2, 5, 6: assemblage B (120 bp, $290 \mathrm{bp}$ ); 3, 4: assemblage AII (70 bp, 80 bp, 90 bp, 120 bp); 7: molecular weight marker 1,000 bp; 8, 9: assemblage BIII (130 bp, $300 \mathrm{bp})$; 10, 11: assemblage BIV (430 bp).

\section{TABLE IV}

Odds ratios (OR) of diarrhoea associated with infection status and bootstrapped $95 \%$ confidence intervals (CI)

\begin{tabular}{lcc}
\hline Infection status & OR & $95 \%$ CI \\
\hline Giardia infection (ELISA-positive) & 3.11 & $2.11,5.10$ \\
Assemblage A & 3.46 & $1.83,9.24$ \\
Assemblage A, group I & NA & NA \\
Assemblage A, group II & 3.74 & $1.93,11.74$ \\
Assemblage B & 2.94 & $1.45,5.81$ \\
Assemblage B, group III & 2.77 & $1.28,6.34$ \\
Assemblage B, group IV & 3.23 & $0.98,10.66$
\end{tabular}

NA: not available.

due to insufficient densities of cysts within the sample. Nested PCR analysis requires a high cyst density and Giardia cysts are susceptible to degradation (Amar et al. 2002). To avoid decreases in cyst density, samples should be frozen soon after collection to prevent degradation by proteases etc. Freeze-thawing of the samples may also be a reason for degradation, suggesting that ELISA and DNA extraction should be performed on fresh samples.

Recent studies (Traub et al. 2004, Sprong et al. 2009) have shown the presence of human genotypes, such as AI and AII, in livestock and pets. Future research on Giardia infection within animal populations in close proximity to humans could address whether or not those Giardia genotypes found in humans are being transmitted zoonotically.

\section{ACKNOWLEDGEMENTS}

To the Ecologica, Desarrollo, Salud y Sociedad project field team, administered out of the Universidad San Francisco de Quito, for their invaluable contributions to specimen and data collection, to the participants of communities surveyed of Cayapas River, Esmeraldas, for giving a faecal sample, and to the Community Health Workers, for informing, preparing, obtaining the consent and translating to the local language in the communities surveyed.

\section{REFERENCES}

Aldana E, Goñi P, Clavel A, de Orantes BC, Buera L 2011. Identificación de genotipos de Giardia duodenalis en niños del area urbana de Guatemala. Rev Ibero-Latinoam Parasitol 70: 25-28.

Amar FL, Dear PH, Pedraza-Díaz S, Looker N, Linnane E, McLauchlin 2002. Sensitive PCR-restriction fragment length polymorphism assay for detection and genotyping of Giardia duodenalis in human feces. J Clin Microbiol 40: 446-452.

Babaei Z, Oormazdi H, Akhlaghi L, Rezaie S, Razmjou E, Soltani-Arabshahi SK, Meamar AR, Hadighi R 2008. Molecular characterization of the Iranian isolates of Giardia lamblia: application of the glutamate dehydrogenase gene. Iranian J Publ Health 37: 75-82.

Bertrand I, Albertini L, Schwartzbrod J 2005. Comparison of two target genes for detection and genotyping of Giardia lamblia in human feces by PCR and PCR-restriction fragment length polymorphism. J Clin Microbiol 43: 5940-5944.

Bhavnani D, Goldstick JE, Cevallos W, Trueba G, Eisenberg JNS 2012. Synergistic effects between rotavirus and coinfecting pathogens on diarrheal disease: evidence from a community-based study in North Western Ecuador. Am J Epidemiol 10: 1093.

Ceu Souza M, Poiares da Silva J 2004. Characterization of human isolates of Giardia lamblia from Portugal. Int J Infect Dis 8: 218.

Cordón GP, Soldan OCP, Vásquez FV, Soto JRV, Bordes LIS, Moreno MS, Rosales MJ 2008. Prevalence of enteroparasites and genotyping of Giardia lamblia in Peruvian children. Parasitol Res 103: 459-465. 
Fallah E, Nahavandi KH, Jamali R, Poor BM, Asqharzadeh M 2008. Molecular identification of Giardia duodenalis isolates from human and animal reservoirs by PCR-RFLP. J Biol Sci 8: 896-901.

Feng Y, Xiao L 2011. Zoonotic potential and molecular epidemiology of Giardia species and Giardiasis. Clin Microbiol Rev 24: 110-140.

García LE, Galván S, Cardoso EJ 2002. Distancia filogenética de aislados de Giardia intestinalis de niños sintomáticos y asintomáticos. Rev Invest Clin 54: 113-118.

Haque R, Roy S, Kabir M, Stroup SE, Mondal D, Houpt ER 2005. Giardia assemblage A infection and diarrhea in Bangladesh. J Infect Dis 192: 2171-2173.

Homan W, Mank T 2001. Human giardiasis: genotype linked differences in clinical symptomatology. Int J Parasitol 31: 822-826.

Jacobson KH, Ribeiro PS, Quist BK, Rydbeck BV 2007. Prevalence of intestinal parasites in young Quichua children in the highlands of rural Ecuador. J Health Popul Nutr 25: 399-405.

Lebbad M, Ankarklev J, Tellez A, Leiva B, Anderson J, Svärds 2008. Dominance of Giardia assemblage B in León, Nicaragua. Acta Trop 106: 44-53.

Minvielle MC, Molina NB, Polverino D, Basualdo JA 2008. First genotyping of Giardia lamblia from human and animal feces in Argentina, South America. Mem Inst Oswaldo Cruz 103: 98-103.

Molina N, Pezzani B, Ciarmela M, Orden A, Rosa D, Apezteguia M, Basualdo J, Minvielle M 2011. Intestinal parasites and genotypes of Giardia intestinalis in school children from Berisso, Argentina. J Infect Dev Ctries 5: 527-534.

Pestehchian N, Rasekh H, Babaei Z, Yousefi HA, Eskandarian AA, Kazemi M, Akbari M 2012. Identification of genotypes of Giardia duodenalis human isolates in Isfahan, Iran, using polymerase chain reaction-restriction fragment length polymorphism. $A d v$ Biomed Res 1: 84.

Read CM, Monis PT, Thompson RC 2004. Discrimination of all genotypes of Giardia duodenalis at the glutamate dehydrogenase locus using PCR-RFLP. Infect Genet Evol 4: 125-130.

Read CM, Walters J, Robertson ID, Thompson RCA 2002. Correlation between genotype of Giardia duodenalis and diarrhoea. Int J Parasitol 32: 229-231.

Rinne S, Rodas EJ, Galer-Unti R, Glickman N, Glickman LT 2005. Prevalence and risk factors for protozoan and nematode infections among children in an Ecuadorian highland community. Trans R Soc Trop Med Hyg 99: 585-592.

Sahagún J, Clavel A, Goñi P, Seral C, Llorente MT, Castillo FJ, Capilla S, Arias A, Gómez-Lus R 2008. Correlation between the presence of symptoms and the Giardia duodenalis genotype. Eur J Clin Microbiol Infect Dis 27: 81-83.

Sprong H, Cacciò SM, van der Giessen JWB 2009. Identification of zoonotic genotypes of Giardia duodenalis. PLoS Negl Trop Dis 3: e558.

Thompson RC, Hopkins RM, Homan WL 2000. Nomenclature and genetic groupings of Giardia infecting mammals. Parasitol Today 16: 210-213.

Traub RJ, Monis PT, Robertson I, Irwin P, Mencke N, Thompson RC 2004. Epidemiological and molecular evidence supports the zoonotic transmission of Giardia among humans and dogs living in the same community. Parasitology 128: 253-262.

Tungtrongchitr A, Sookrung N, Indrawattana N, Kwangsi S, Ongrotchanakun J, Chaicumpa W 2010. Giardia intestinalis in Thailand: identification of genotypes. J Health Popul Nutr 28: 42-52. 